\title{
Evaluation of Marginal Microgaps of Two Glass-ionomer Cements (GIC) in Dogs and Sheep in vivo
}

\author{
M. FIGUROVÁ, V. LEDECKÝ, S. ŠTVRTINA ${ }^{1}$
}

Clinic of Surgery, Orthopaedics and Roentgenology, University of Veterinary Medicine in Košice, Slovakia

${ }^{1}$ Medical Faculty of Komenský University in Bratislava, Slovakia

Received February 7, 2005

Accepted April 13, 2006

\begin{abstract}
Figurová, M., V. Ledecký, S. Štvrtina: Evaluation of Marginal Microgaps of Two Glassionomer Cements (GIC) in Dogs and Sheep in vivo. Acta Vet. Brno 2006, 75: 403-410.

The aim of the experiment was to evaluate the marginal microgaps of two ionomer cements: Kavitan Plus (Spofa Dental) and Vitremer (3M ESPE) in dog and sheep dentition in vivo.

Dentitions of sheep and dogs were restored in vivo with a conventional, glass polyalkenoic, chemically activated cement Kavitan Plus with hydrophilic properties capable and with a resinmodified glass-ionomer cement Vitremer with light-induced polymerization and autopolymerization reaction of methyl metacrylate group.

The parameters of glass-ionomers were evaluated in 6 groups of animals, 2 animals in each, at various time intervals (after 1, 4 and 6 months in dogs and 3, 6 and 9 months in sheep, starting from the beginning of the experiment). The restorative materials were placed to buccal surfaces of permanent teeth. At the intervals specified, under general injection anaesthesia, throughout the experiment we extracted 24 teeth from sheep and 30 from dogs. When processing the samples of dog's teeth two samples were damaged. One month after the placement, Kavitan plus restorations became loose only in one case in dogs ( $80 \%$ successfulness). In sheep two Kavitan Plus restorations became loose after 9 months (50\% successfulness). During the experiment we observed neither cracks nor marginal discoloration in both Kavitan Plus and Vitremer restorations. Statistically significant $(P=0.04)$ differences were observed in the dentin of dogs receiving glass-ionomer Vitremer restorations which exhibited lower marginal microgaps. The remaining results were non- significant (ANOVA test). Fluoride ions released from GIC support the treatment of dental hard tissues. These materials could be used as definitive restorations of class A - D cavities in dogs and dental cervical caries in sheep as well as underlying layers of composite and amalgam materials.
\end{abstract}

Glass-ionomer cement, experiment, dentition, incisors, premolars, histology, microgaps, restoration

Veterinary stomatology faces high prevalence of periodontitis. The second most frequent stomatologic diagnosis in carnivores are various types of teeth fractures with or without open pulp cavities the therapy (Capík 2005; Nemec et al. 2005). Less frequent are dental caries, luxation of teeth, enamel hypoplasia and tumours.

The treatment of enamel hypoplasia disease is based on stomatological restorations. The use of restorations in the treatment of various degrees of enamel hypoplasia was described by Capík (1996). Due to limited possibility of cavity preparation and intensive masticatory forces in dogs (about 10 times stronger than in humans) the lifetime of restorations of extensive defects in the coronal third of the crown is much shorter compared to those in the apical part of the crown.

Caries dentini is a disease manifested by decay of dental hard tissues. Its development is conditional on the presence of caries-susceptible teeth, micro-organisms and food. The overall incidence of caries in dogs ranges between 5-35\%. The most frequently affected teeth are first maxillary molars and first and second mandibular molars (Capík et al. 1999). The low incidence of caries in dogs has been attributed particularly to increased neutralising and antibacterial properties of dog saliva.

Address for correspondence:

MVDr. Mária Figurová

Department of Surgery

University of Veterinary Medicine

Komenského 73,041 81 Košice, Slovak Republic
Phone: +421556337832

Fax: +421 556337832

E-mail: composite@orangemail.sk

http://www.vfu.cz/acta-vet/actavet.htm 
Hale (1998) recorded a $40 \%$ incidence of caries in pits and fissures of canine teeth, 36\% incidence of surface crown caries, and $23 \%$ incidence of root caries. Because of considerably different anatomy of human and animal teeth the Black's system of cavity description has not been generally accepted. With carnivores a system developed by Harvey and Emily has been used which divides the dental damage and caries into 6 classes, A, B, C, D, E, F, according to the location (Harvey and Emily 1993).

In the stomatological practice we use different types of restorations. Glass-ionomer cements (GIC) are restorative materials of a new generation which, with regard to their hydrophilic nature, adherence to hard dental tissues and gradual release of fluoride ions, became important restorative materials for dental cervical caries and lesions (Glas s poole and Ericks on 1993). GICs are composed of a basic glass and an acidic polymer. The acidbase reaction of these two components is typical only of this type of restorative materials (McLean et al. 1994). Enrichment of GIC with resins (hybrid, resin-modified GIC) or metals (metal ionomers) ensures better physical properties of restorations compared to conventional poly(alkenoic) GIC.

The mechanism of chemical adhesion between GIC and dental hard tissues ensures minimum to nil microleakage (Attin at al. 1995) and minimises the quantity of dentin that has to be removed by drilling during the preparation.

Marginal leakage may result in various pulp pathologies, development of secondary caries and discoloration adjacent to restorations. The biggest problem concerning marginal adaptation is associated with the zone of cement/dentinal interface which is known for high humidity of the operative field. Negative factors related to polymerisation shrinkage and thermal expansion resulted in post-operative sensitivity of composites (Mitra and Conway 1994). GIC showed minimum variations of the coefficient of thermal expansion (Puckett et al. 1995).

Despite the shortcomings of GIC, such as low mechanical resistance, sensitivity to a very dry or very humid environment, these materials are justified in some situations in which composites or amalgams appear unsuitable. Owing to them a mineralisation mound develops which is registered in the process of reconstruction of impaired dentin (Khou wLiu et al. 1999). Their anticariogenic effect has been confirmed also in the environment supporting the dental caries. The effect of acids on the surface of GIC was less pronounced in comparison with composites (Glas s poole and Ericks on 1993; Park and Kim 1997; Donly and Grandgenett 1998).

A smear layer fills up the orifice of dentinal tubules. It contains small particles of collagen matrix, saliva, bacteria, tubular fluid and blood elements. The studies focusing on adhesion of GIC to hard dental tissues use two different procedures. These procedures are based on preservation or removal of the smear layer. Polyalkenoate GIC higher strength of GIC Fuji II LC after removal of the smear layer. The samples with GIC Fuji IX and Photac-Fil Quick, with and without a conditioner, showed no significant differences (Tanumiharja et al. 2000).

The aim of the experiment was to evaluate the marginal microgaps of two ionomer cements: Kavitan Plus (Spofa Dental) and Vitremer (3M ESPE) in dog and sheep dentition in vivo. Two animal species differring widely by the type of dentition, and processing of food were selected. These differences and the respective intraoral conditions may affect the restorations used in the experiment.

\section{Materials and Methods}

The experiment was carried out between June 2002 and May 2003 at Clinic of Surgery, Orthopaedics and Roentgenology, UVM Košice, accredited for experiments on animals conducted for scientific purposes (Act No. 115/95 of the Civil Code on Animal Protection), accreditation No. 12 766/02-220.

Two GIC were used to reconstruct class A cavities: Kavitan Plus (K), a chemically activated cement belonging to 
the group of conventional glass polyalkenoic cements, and resin-modified Vitremer (V) which, besides light-induced polymerisation exhibits also autopolymerisation reaction of metacrylate group radicals without access of light. We evaluated the following parameters: marginal microgaps, colour stability, quality and retention of restorations of class A cavities in vivo. The experiment was conducted on animals with healthy dental tissues. The parameters of glass ionomers were evaluated in 6 groups of animals, 2 animals in each at various time intervals (at 1, 4 and 6 months in dogs and 3, 6 and 9 months in sheep after the beginning of the experiment). At the above-mentioned intervals, we extracted and evaluated 4 incisors and 4 premolars from sheep (a total of 24 teeth) and 6 incisors and 4 premolars from the dogs (a total of 30 teeth) under general injection anaesthesia. When processing the samples of canine teeth two samples were damaged. Histological and statistical data are therefore based on 28 teeth.

\section{Preparation procedure}

Calculus was cleaned off the teeth and isolated from the buccal mucosa by means of paper cylinders. The prepared class A cavities were on the buccal surface of teeth. Those located on the left side of dentitions were restored with GIC Kavitan Plus and those on the right side were restored with GIC Vitremer.

When using GIC Kavitan Plus we did not disturb the smear layer so we could observe the influence of this layer on the quality of restorations.

The powder was homogenised by shaking. The ratio of powder to liquid was 1:1. The procedure used complied with that recommended by the producer but the dentinal conditioner was omitted. After solidification, the excess material was removed and the restoration was coated with a protective glaze of LC Varnish.

Before application of Vitremer we used a primer which adjusted the smear layer. The procedure used corresponded fully to the manufacturers' instructions. After setting, the excess material was removed and the restoration was covered with a protective coat. Preparation of class A cavities and their restoration was carried out on animals under general anaesthesia. Premedication of all animals was achieved by administration of atropin a.u.v. at a dose of $0.05 \mathrm{mg} \cdot \mathrm{kg}^{-1} \mathrm{i} . \mathrm{m}$. The general anaesthesia in dogs was induced by i.m. administration of a combination of xylazin a.u.v. and ketamin a.u.v. at a dose of $1-2 \mathrm{mg} \cdot \mathrm{kg}^{-1}$ and $5-10 \mathrm{mg} \cdot \mathrm{kg}^{-1}$, respectively. The general anaesthesia in sheep was induced by i.m. administration of a combination of xylazin a.u.v. and ketamin a.u.v. at a dose of $0.4 \mathrm{mg} \cdot \mathrm{kg}^{-1}$ and 5-10 mg. $\mathrm{kg}^{-1}$, respectively. During the experiment the dogs were fed a combined diet consisting of dry granules and a soft component.

The preparation of histological specimens differed from the conventionally used procedure. Histological sections were not dehydrated. To ensure correct interpretation, care had to be taken to avoid undue dehydration of sections during processing and observation. The extracted teeth were conserved with $10 \%$ formalin. Specimens were prepared using water-hardened cyanoacrylates. Sections were cut with a diamond saw and after hardening were embedded in solacryl. They were prepared longitudinally and their thickness ranged between 100 and $150 \mu \mathrm{m}$ (Plate III, Fig. 5, 6). The width of microgaps was measured in $\mu \mathrm{m}$ separately for the dentin and enamel. Statistical evaluation of the size of microgaps was carried out by ANOVA.

\section{Results}

\section{Clinical evaluation}

Sheep

All restorations in 3 groups (each $n=2$ ) were intact and showed no marginal discoloration. In Group $3(\mathrm{n}=2)$ of animals (9 months after the beginning of the experiment) Two restorations with GIC Kavitan Plus showed signs of separation (50\% successfulness). Neither cracks nor marginal discoloration was observed in the remaining restorations (Table 1). No health complications occurred in the animals throughout the experiment and their food intake and digestion corresponded to their physiology.

Table 1. Retention and colour stability of GIC in sheep dentition

\begin{tabular}{|l|l|c|c|c|c|}
\hline \multicolumn{1}{|c|}{ Sheep } & Material & $\begin{array}{c}\text { Number of } \\
\text { evaluated teeth }\end{array}$ & $\begin{array}{c}\text { Number of } \\
\text { teeth with } \\
\text { separation of } \\
\text { restorations }\end{array}$ & $\begin{array}{c}\text { Retention of } \\
\text { restorations } \\
\%\end{array}$ & $\begin{array}{c}\text { Colour } \\
\text { stability } \\
\%\end{array}$ \\
\hline \multirow{2}{*}{$\begin{array}{l}1^{\text {st }} \text { group (after 3 } \\
\text { months) }\end{array}$} & Vitremer & 4 & - & 100 & 100 \\
\cline { 2 - 6 } & Kavitan Plus & 4 & - & 100 & 100 \\
\hline $\begin{array}{l}2^{\text {nd }} \text { group (after 6 } \\
\text { months) }\end{array}$ & Vitremer & 4 & - & 100 & 100 \\
\cline { 2 - 6 } & Kavitan Plus & 4 & - & 100 & 100 \\
\hline $\begin{array}{l}3^{\text {rd }} \text { group (after 9 } \\
\text { months) }\end{array}$ & Vitremer & 4 & - & 50 & 100 \\
\cline { 2 - 6 } & Kavitan Plus & 4 & 2 & & 100 \\
\hline
\end{tabular}


Dogs

Restorations in all groups (each $\mathrm{n}=2$ ) were intact and showed no discoloration.

In the $4^{\text {th }}$ group of animals (dogs after 1 month of the experiment) $100 \%$ retention of all resin-modified GIC was observed. One chemically activated GIC restoration showed signs of separation i.e. successfulness of treatment was $80 \%$ (Table 2). The dogs showed no signs of health problems throughout the experiment their food intake and digestion was physiological.

Table 2. Retention and colour stability of GIC in canine dentition

\begin{tabular}{|c|c|c|c|c|c|}
\hline Sheep & Material & $\begin{array}{c}\text { Number of } \\
\text { evaluated teeth }\end{array}$ & $\begin{array}{l}\text { Number of } \\
\text { teeth with } \\
\text { separation of } \\
\text { restorations }\end{array}$ & $\begin{array}{l}\text { Retention of } \\
\text { restorations } \\
\%\end{array}$ & $\begin{array}{c}\text { Colour } \\
\text { stability } \\
\%\end{array}$ \\
\hline \multirow{2}{*}{$\begin{array}{l}4^{\text {th }} \text { group (after } 1 \\
\text { month) }\end{array}$} & Vitremer & 5 & - & 100 & 100 \\
\hline & Kavitan Plus & 5 & 1 & 80 & 100 \\
\hline \multirow{2}{*}{$\begin{array}{l}5^{\text {th }} \text { group (after } 4 \\
\text { months) }\end{array}$} & Vitremer & 5 & - & 100 & 100 \\
\hline & Kavitan Plus & $4^{*}$ & - & 100 & 100 \\
\hline \multirow{2}{*}{$\begin{array}{l}6^{\text {th }} \text { group (after } 6 \\
\text { months) }\end{array}$} & Vitremer & $4^{*}$ & - & 100 & 100 \\
\hline & Kavitan Plus & 5 & - & 100 & 100 \\
\hline
\end{tabular}

*One sample was damaged during processing

\section{Histology}

Methods used: 3-factorial dispersion analysis of repeated measurements (method, tooth, measurement) was performed.

The measurements in sheep showed that the mean span of microgaps between dentin and Kavitan Plus GIC was $15.6 \mu \mathrm{m}$ and Vitremer GIC restorations was $15.0 \mu \mathrm{m}$, resp. Current effect: $\mathrm{F}(1,4)=0.03$, probability $P=0.87$ (Fig. 1). As $\mathrm{P}$ was higher than 0.05 , the nil hypothesis which claims that the means at the $5 \%$ level of significance are equal could not be rejected.

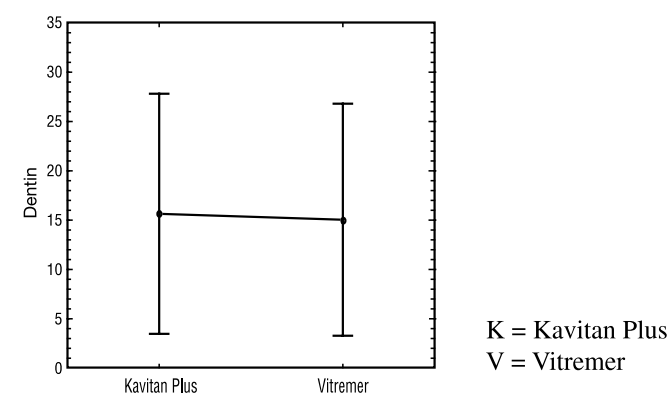

Fig. 1. Evaluation of marginal leakage in $\mu \mathrm{m}$ at sheep dentin

$\mathrm{K}=$ Kavitan Plus, $\mathrm{V}=$ Vitremer

Mean $\mathrm{K}=15.6 \mu \mathrm{m} \mathrm{V}=15.0 \mu \mathrm{m}$. Statistical significance of differences between means was determined by F-statistics. 
Significant differences $(P=0.04)$ between the span of microgaps with the two restoration materials used were observed in dogs as the respective mean spans were $16.2 \mu \mathrm{m}$ and 12.6 ûm with Kavitan Plus and Vitremer GIC, resp. Current effect: $\mathrm{F}(1,6)=6.70, P=0.04$, statistically significant (Fig. 2).

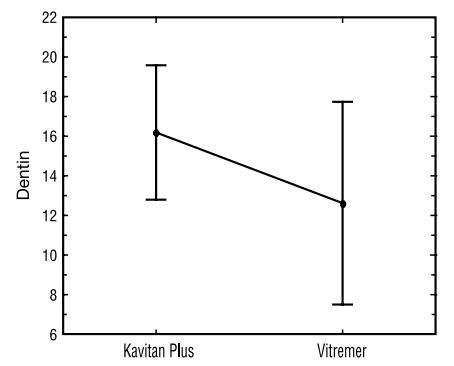

Fig. 2. Evaluation of marginal leakage in $\mu \mathrm{m}$ at dog dentin

Mean $\mathrm{K}=16.2 \mu \mathrm{m}, \mathrm{V}=12.6 \mu \mathrm{m}$

Current effect: $\mathrm{F}(1,6)=6.70, P=0.04$, statistically significant.

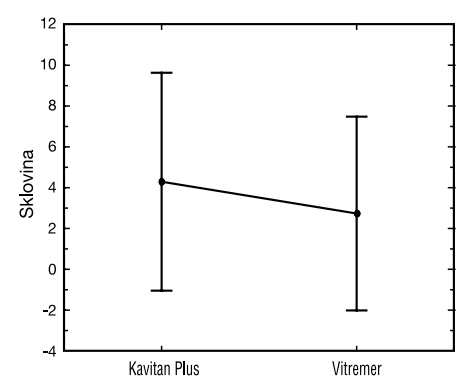

Fig. 3. Evaluation of marginal leakage in $\mu \mathrm{m}$ at sheep enamel

Mean $\mathrm{K}=4.3 \mu \mathrm{m}, \mathrm{V}=2.7 \mu \mathrm{m}$

Current effect: $\mathrm{F}(1,5)=0.54, P=0.50$, non-significant

The microgaps between sheep's enamel and Kavitan Plus GIC was $4.3 \mu \mathrm{m}$ and Vitremer GIC restorations was $2.7 \mu \mathrm{m}$. Current effect: $\mathrm{F}(1,5)=0.54, P=0.50$, NS (Fig. 3).

Results of microgaps between dog's enamel and Kavitan Plus $(2.15 \mu \mathrm{m})$ GIC and Vitremer GIC $(2.85 \mu \mathrm{m})$ restorations were non-significant. Current effect: $F(1,6)=0.10$, $P=0.80$, NS (Fig. 4).

The span of microgaps at dentin, enamel and both GIC measured in our study had no effect on the development of pathological changes in dental tissues and marginal discoloration.

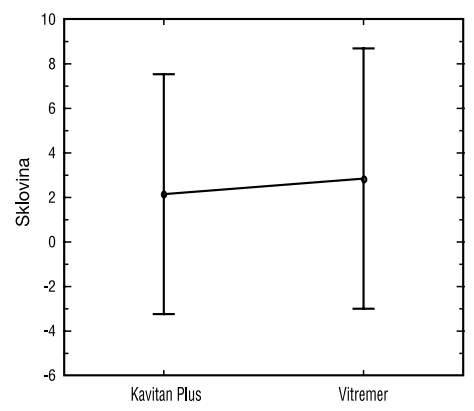

Fig. 4. Evaluation of marginal leakage in $\mu \mathrm{m}$ at dog enamel

Mean $\mathrm{K}=2.15 \mu \mathrm{m}, \mathrm{V}=2.85 \mu \mathrm{m}$

Current effect: $\mathrm{F}(1,6)=0.10, P=0.80, \mathrm{NS}$

\section{Discussion}

The study describes real application of GIC in stomatological practice. Owing to their hydroscopic properties, GIC produce tight bond with dental hard tissues within the first 24 hours (Attin et al. 1995). This high marginal adaptation prevents ingress of fluids and bacteria 
into the tooth which results in colour stability of restorations and decreased irritation of the pulp.

With regard to the release of fluoride ions and thermal expansion of GIC which resembles that of dentin and enamel, GIC have been advocated for the restoration of dental cervical lesions and caries (Abdalla and Alhadainy 1997; Harvey and Emily 1993). The results obtained in our study proved that better bonding of GIC was obtained with enamel apatite than with dentinal collagen fibres. Our measurements showed that the mean span of microgaps at enamel was between 2.15 and $4.3 \mu \mathrm{m}$ whereas that at dentin ranged between 12.6 and $16.2 \mu \mathrm{m}$. Rigsby et al. (1990) used various dentin bonds (in composites) for cervical lesions and reported that the size of microgaps was between 5.5 and $18 \mu \mathrm{m}$. A two year study of GIC and compomer showed 90 - 100\% successfulness with regard to retention and marginal adaptation of restorations. Compared to GIC, the compomer showed better colour stability of restorations as the reported colour stability of GIC was only $67-85 \%$ (Abdalla and Alhadainy 1997). Our study showed that after 9 months of the experiment in sheep and 6 months in dogs no marginal discoloration of restorations with both materials used was observed.

The studies of Najar et al. (2003) did not show increased adhesion of some GIC to dental hard tissues after removal of the smear layer. In vitro studies on bovine incisors point to increased adhesion of resin-modified GIC and compomers to conditioner-adjusted dentin (B u challa et al. 1996). Better adhesion of experimental GIC to dentin of bovine incisors was obtained with the presence of the smear layer (Lalh et al. 1999).

Different intraoral conditions and dentin types affected the life-span of restorations when the smear layer was retained. Our experiments in sheep pointed to importance of adjustment of the smear layer as its preservation resulted in only $50 \%$ successfulness of Kavitan Plus GIC restorations after 9 months. Adjustment of dentin before placement of Vitremer restorations ensured $100 \%$ successfulness of treatment.

After 6 months of the experiment of the restorations with Kavitan Plus (smear layer retained) and Vitremer GIC (smear layer adjusted) in dogs exhibited 100\% success. The adjustment of smear layer before placement of Kavitan Plus GIC was not inevitable. Retention of this layer (filling the orifice of dentinal tubules) may decrease the postoperative sensitivity important particularly in young animals having a very thin dentin layer lining the pulpal cavity.

Caries of classes A, D and F are most frequent in dogs. High degree of successfulness (82\%) was reached used composites in the treatment of class A caries (Capík et al. 1999). The lifespan of restorations used with class D caries was 6 months. Class F involved decay of dental tissue resembling osteoclastic resorption without presence of caries. Class D caries affect cemento-enamel junction and are associated with pulpal damage. The GIC used in our study in dogs proved successful in locations with higher humidity (cervical zone) owing to their hydrophilic character. Their ability to release fluoride ions prevents demineralisation of dentin and ensures its better regeneration. This was not observed with composites (Donly and Grandgenett 1998).

Veterinary practice in the country and abroad indicates that the category of pets includes besides carnivores, such as cats and dogs, also other animal species, e.g. herbivores, pigs and others. This wide spectrum of animals forces veterinary stomatologists to use restoration materials developed more likely for humans than for animals. Because of that we included in our experiment not only carnivores but also ruminants with such anatomy of dentition and processing of feed that can influence the overall use of GIC.

The results of our experiment proved that both conventional and resin-modified GIC can be used successfully in the treatment of dental cervical defects. No pathological intake and processing of feed was observed. 
The use of GIC Vitremer and Kavitan Plus in veterinary stomatology is well-founded. They are advantageous particularly in locations in which the dry environment needed for application of amalgam and composites cannot be ensured. The most suitable location for application of GIC is the dental cervical zone. Neither cracks nor discoloration were observed in restorations. Present smear layer with Kavitan Plus was part of our experiment investigating the lifetime of restorations when the smear layer was retained in various types of dentitions and intraoral environments. It was based on the studies of Mitra and Con way (1994) and Puckett et al. (1995) who observed the lowest thermal expansion particularly with conventional GIC. Our results, particularly those in sheep, indicated the necessity of adjustment of the smear layer with a conditioner because in the $9^{\text {th }}$ month of the experiment two Kavitan Plus restorations showed signs of separation. In the $6^{\text {th }}$ month of the experiment in dogs $100 \%$ successfulness of restorations with Kavitan Plus was observed. The size of microgaps measured at dog dentin was significant but resulted in no pathogenic states in the pulp or hard dental tissues.

Fluoride ions released from GIC support the treatment of dental hard tissues. These materials could be used as definitive restorations of class A and D cavities in dogs and dental cervical caries in sheep as well as underlying layers of composite and amalgam materials.

\section{Hodnotenie okrajových netesností pri použití dvoch skloionomérnych cementov (SC) in vivo u psov a oviec v experimente}

Cielom experimentálneho štúdia bolo zhodnotit parametre okrajových netesností dvoch skloionomérnych cementov: Kavitan Plus (Spofa Dental) a Vitremer (3M ESPE) in vivo na chrupe psov a oviec.

U psov a oviec sme in vivo použili klasický sklopolyalkenoátový chemicky tuhnúci cement s hydrofilnými vlastnostami Kavitan Plus a živicovo-modifikovaný skloionomérny cement Vitremer, ktorý okrem svetelnej polymerizácie využíva autopolymerizačnú reakciu radikálov metakrylátových skupín bez prístupu svetla.

Parametre skloionomérov sme hodnotili v 6 skupinách zvierat po 2 ks v rôznych časových intervaloch (u psov po 1. 4. a 6. mesiaci a u oviec po 3. 6. a 9. mesiaci od začiatku experimentu). Výplne boli umiestnené na bukálnej ploche trvalého zubu. V daných intervaloch sme v celkovej injekčnej anestézii extrahovali u oviec (v jednej skupine) 4 rezáky a 4 črenovce (premoláre) a u psov (v jednej skupine) 6 rezákov a 4 premoláre. Počas celého experimentu sa v celkovej anestézii extrahovalo u oviec 24 zubov a u psov 30 zubov. Pri spracovaní vzoriek z psích zubov došlo k poškodeniu dvoch vzoriek. Histologické a štatistické údaje vychádzajú z počtu 28 zubov. U psov sme po 1 . mesiaci zaznamenali jeden prípad uvolnenia (vypadnutia) výplne Kavitanu Plus (úspešnosṫ výplne $80 \%$ ). U oviec sme po 9 mesiacoch experimentu zistili uvolnenie dvoch výplní Kavitanu Plus (úspešnosṫ výplne 50 \%). Výplne cementami Kavitan Plus a Vitremer boli počas experimentu bez prasklín a bez okrajových farebných zmien. Štatisticky významný rozdiel $(P=0.04)$ sa pozoroval pri dentíne u psov, kde pri výplniach s použitím skloionomérného cementu Vitremer sme zaznamenali nižšie hodnoty okrajových netesností. Ostatné výsledky boli štatisticky nevýznamné (ANOVA test).

Podporná liečba tvrdých zubných tkanív je zabezpečená fluoridovými iónmi uvolňovanými zo SC. Tieto materiály sa môžu použit ako definitívne výplne krčkových kavít typu A až D u psov a krčkových kavít u oviec ako aj podložky pod kompozitné a amalgámové materiály.

\section{Acknowledgement}

The authors wish to express their thanks to the company AKVÁRIUM KOBOLKA Nové Zámky and Mrs. Cedidlová from DELIKA who kindly supplied granulated feed for the dogs during the experiment. 


\section{References}

ABDALLA AI, ALHADAINY HA 1997: Clinical evaluation of hybrid ionomer restoratives in Class V abrasion lesions: Two-year results. Quintessence Int 28: 255-258

ATTIN T, BUCHALLA W, KIELBASSA AM, HELLWIG E 1995: Curing shrinkage and volumetric changes of resin-modified glass ionomer restorative materials. Dent Mater 11: 359-62

BUCHALLA W, ATTIN T, HELLWIG E 1996: Influence of dentin conditioning on bond strength of light-cured ionomer restorative materials and polyacid-modified composite resins. J Clin Dent 7: 81-4

CAPÍK I 1996: Hypoplasia of enamel in dogs (In Slovak). Infovet 5: 38-39

CAPÍK I 2005: Resistance of fractured canine teeth reconstructed by cast metal crowns with integrated post against pressure in vitro. Proceedings of the 14 th European Congress of Veterinary Dentistry, Ljubljana 2005, pp. $49-51$

CAPÍK I, LEDECKÝ V, ŠEVČÍK A 1999: Non-traumatic diseases of dental hard tissues in dogs and possibilities of their therapy (In Slovak). Veterinářství 8: 332-335

DONLY KJ, GRANDGENETT G 1998: Dentin demineralization inhibition at restoration margins of Vitremer, Dyract and Compoglass. Am J Dent 11: 245-248

GLASPOOLE EA, ERICSON RL 1993: In vitro investigation of the caries inhibiting effect of fluoride releasing materials. J Dent Res 72: abstr. 1448

HALE FA 1998: Dental caries in the dog. J Vet Dent 15: 79- 83

HARVEY CE, EMILY PP 1993: Restorative Dentistry. Small Animal Dentistry. Mosby 1993, pp. 213-215

KHOUW-LIU VHW, ANSTICE HM, PEARSON GJ 1999: An in vitro investigation of a poly(vinyl phosphonic acid) based cement with four conventional glass - ionomer cements. Part 1: flexural strength and fluoride release. J Dent 27: 351-357

LALH MS, TITLEY K, TORNECK CD, FRIEDMAN S 1999: The shear bond strength of glass ionomer cement sealers to bovine dentine conditioned with common endodontic irrigants. Int Endod J 32: 430-435

MCLEAN JW, NICHOLSON JW, WILSON AD 1994: Proposed nomenclature for glass ionomer dental cement and related materials. Quintessence Int 25: 587-589

MITRA SB, CONWAY WT 1994: Coeficient of thermal expansion of some methacrylate-modified glass-ionomer (abstract 944). J Dent Res 73: 219

NAJAR AL, SAQUY PC, VANSAN LP, SOUSA-NETO MD 2003: Adhesion of a glass- ionomer root canal sealer to human dentine. Aust Endod J 29: 20-22

NEMEC A, PAVLICA Z, PETELIN M, ERŽEN D, CROSSLEY DA 2005: Fractured canine teeth in dogs in Slovenia: fracture types and treatment performed. Proceedings of the 14 th European Congress of Veterinary Dentistry. Ljubljana 2005, pp. 52-54

PUCKETT AD, FITCHIE JG, BENNETT B, HEMBREE JH 1995: Microleakage and thermal properties of hybrid ionomer restoratives. Quintessence Int 26: 557-581

PARK SH, KIM KY 1997: The anticariogenic effect of fluoride in primer, bonding agent, and composite resin in the cavosurface enamel area. Oper Dent 22: 115-20

RIGSBY DF, RETIEF DH, RUSSELL CM, DENYS FR 1990: Marginal leakage and marginal gap dimensions of three dentinal bonding systems. Am J Dent 3: 289-294

TANUMIHARJA M, BURROW MF, TYAS MJ 2000: Microtensile bond strenght of glass ionomer (polyalkenoate) cement to dentine using four conditioners. J Dent 28: 361-366 
Plate III

Figurová M. et al.: Evaluation of marginal ... pp. 403-410

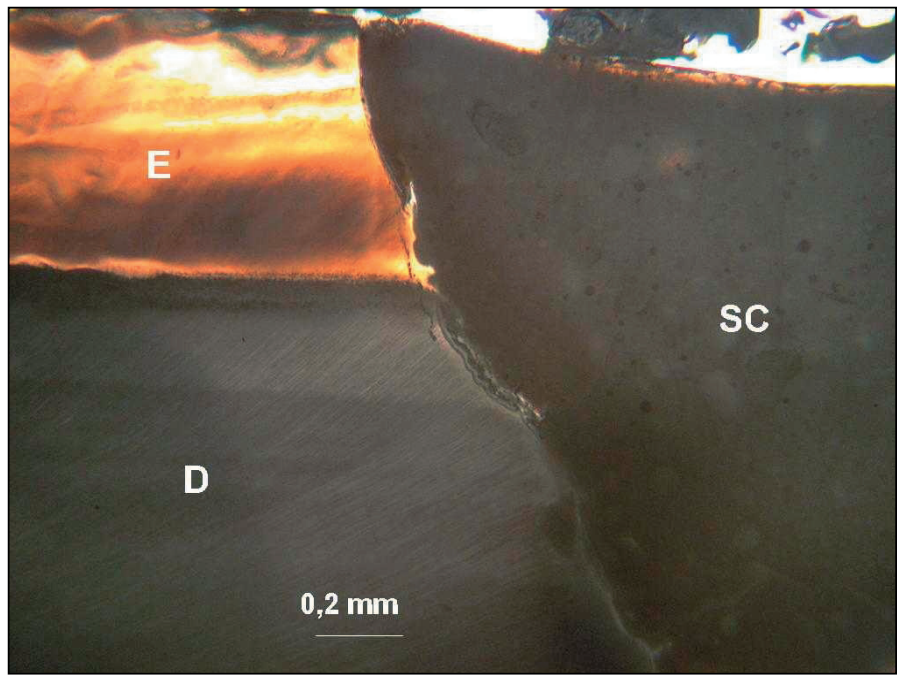

Fig. 5. Sheep tooth with GIC (SC) Kavitan Plus, native, magnification $\times 5$, bar $0.2 \mathrm{~mm}$ Enamel (E)

Dentin (D)

Glass-ionomer cement (SC)

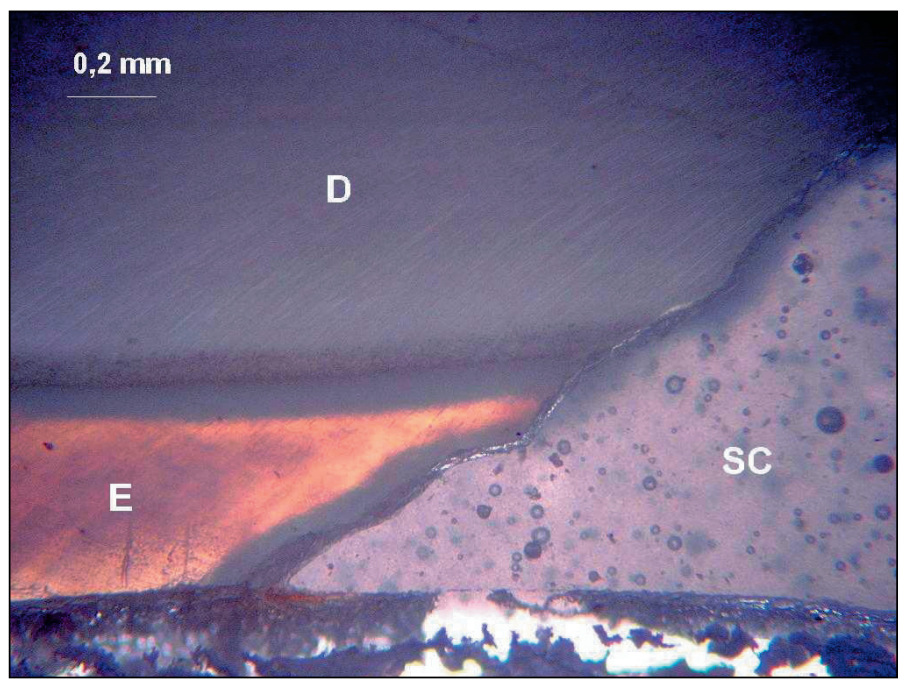

Fig. 6. Sheep tooth with GIC (SC) Vitremer, native, magnification. $\times 5$, bar $0.2 \mathrm{~mm}$ Enamel (E)

Dentin (D)

Glass-ionomer cement (SC) 


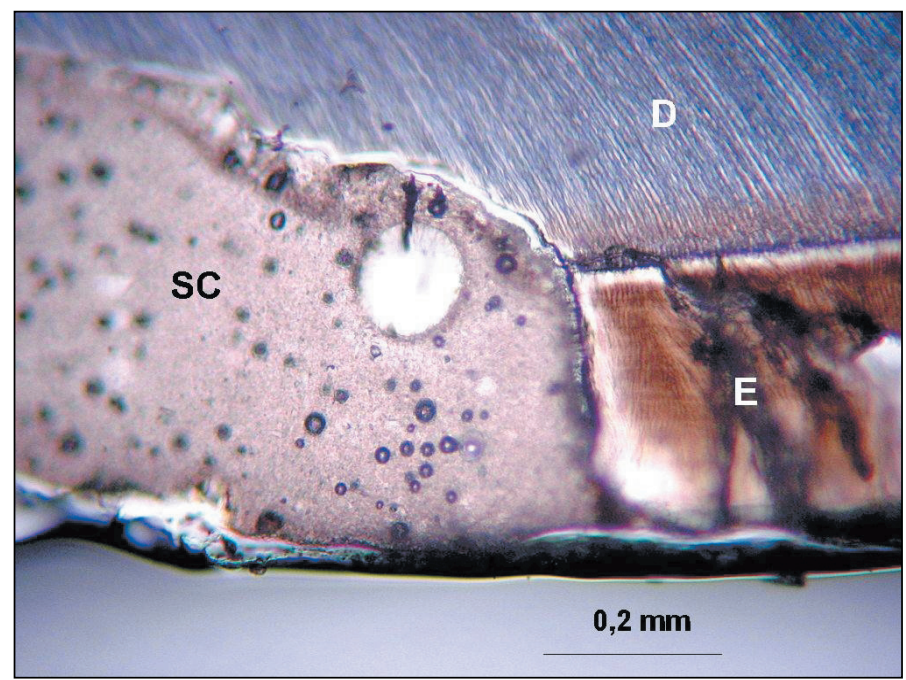

Fig. 7. Canine tooth with GIC (SC) Kavitan Plus, native, magnification $\times 10$, bar $0.2 \mathrm{~mm}$

Enamel (E)

Dentin (D)

Glass-ionomer cement (SC)

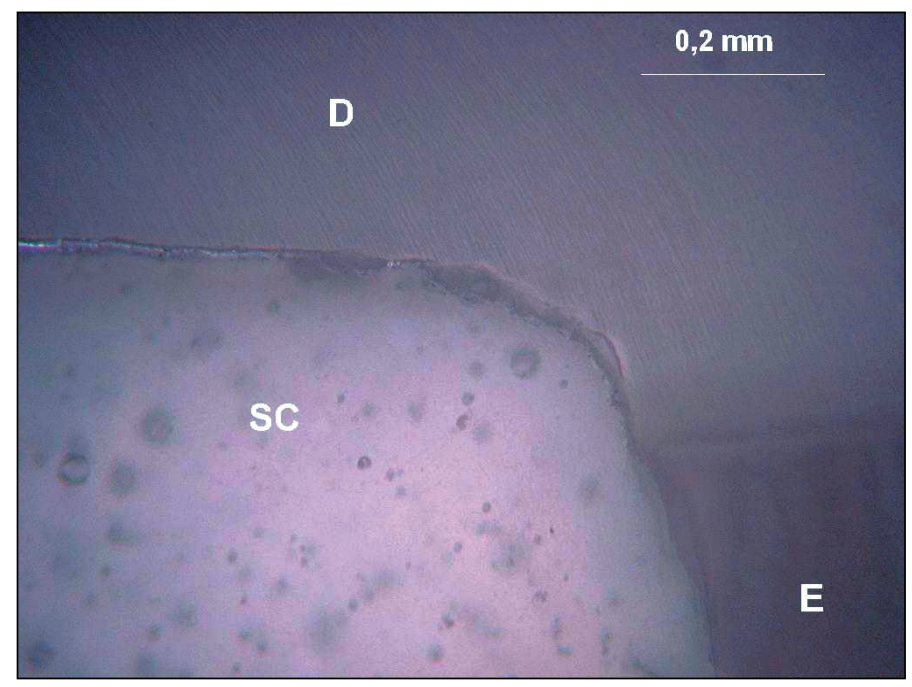

Fig. 8. Canine tooth with GIC (SC) Vitremer, native, magnification $\times 10$, bar $0.2 \mathrm{~mm}$

Enamel (E)

Dentin (D)

Glass-ionomer cement (SC) 